Пастовенський, О.В.(2016). Синергетичний сценарій розвитку ефективних освітніх систем. Вісник Житомирського державного університету імені Івана Франка. Вип. 2 (84). С. 102-106.

Аверьянов, В. Б. (1979). Функции и организационная структура органа государственного управления. Київ: Наукова думка. 150 с.

\section{REFERENCES}

Pro povnu zahalnu seredniu osvitu: Zakon Ukrainy vid 16 sichnia 2020 roku № 463-IX [On complete general secondary education: Law of Ukraine, January 16, 2020 № 463IX]. URL: https:// https://zakon.rada.gov.ua/laws/show/46320\#Text (data zvernennia: 17.05.2021). [in Ukrainian].

Kravchenko, S. A. (2004). Sotsyolohycheskyi entsyklopedycheskyi russko-anhlyiskyi slovar: bolee 10000 edynyts [Sociological Encyclopedic Russian-English Dictionary]. Moskva: OOO «Yzdatelstvo Astrel»: OOO «Yzdatelstvo AST»: OOO «Tranzytknyha». $511 \mathrm{~s}$. [in Russian].

Shehda, A. V. (2004). Menedzhment [Management]: pidruchnyk. Kyiv: Znannia. 687 s. [in Ukrainian].

Yelnykova, H. V. (1999). Naukovi osnovy rozvytku upravlinnia zahalnoiu serednoiu osvitoiu v rehioni [Scientific basis for the regional development of middle education management]. Kyiv: DAKKO. 303 s. [in Ukrainian].
Luniachek, V. E. (2015). Pedahohichnyi menedzhment [Pedagogical management]: navchalnyi posibnyk. 2-e vyd., vypr. Kharkiv: Vyd-vo KharRI NADU «Mahistr». 512 s. [in Ukrainian].

Kravchenko, V. O. (2012). Osnovy menedzhmentu [Basics of management]: navchalnyi posibnyk. Odesa: Atlant. 212 s. [in Ukrainian].

Marmaza, O. I. (2017). Menedzhment osvitnoi orhanizatsii [Management of educational institution]. Kharkiv: TOV «Shchedra sadyba». 126 s. [in Ukrainian].

Rosokha, V. V., Hazuda, L. M. (2013). Osoblyvosti planuvannia v systemi marketynhovoho menedzhmentu [Features of planning in marketing management systems]. Naukovyi visnyk Uzhhorodskoho universytetu. Seriia «Ekonomika». Vyp. 2 (39). Ch. 1. S. 223-233. [in Ukrainian].

Pastovenskyi, O. V. (2016). Synerhetychnyi stsenarii rozvytku efektyvnykh osvitnikh system [Synergistic scenario for the development of effective educational systems]. Visnyk Zhytomyrskoho derzhavnoho universytetu imeni Ivana Franka. Vyp. 2 (84). S. 102-106. [in Ukrainian].

Averianov, V. B. (1979). Funktsyy y orhanyzatsyonnaia struktura orhana hosudarstvennoho upravlenyia [Functions and organizational structure of public authorities]. Kyiv: Naukova dumka. 150 s. [in Russian].

Дата надходження до редакиї: 21.05.2021 p.
УДК 378 016:373.5.011.3-051(4)

DOI: $10.37026 / 2520-6427-2021-107-3-41-47$

\section{Руслана СОЙЧУК,}

доктор педагогічних наук, професор, завідувач кафедри педагогіки початкової, інклюзивної та вищої освіти

Рівненського державного

гуманітарного університету, м. Рівне, Украӥна

ORCID: 0000-0001-5559-5388

e-mail: ruslanasoichuk@gmail.com

\title{
СУЧАСНІ ВИМОГИ ДО МАЙБУТНЬОГО ПЕДАГОГА ОБ'ЄДНАНОЇ ЄВРОПИ ХХІ СТОЛІТТЯ
}

\begin{abstract}
Анотація. У статті актуалізовано та схарактеризовано сучасні вимоги до майбутнього педагога об'єднаної Свропи. Розкрито головні завдання освіти ŭ педагогічної діяльності викладача в контексті європейських інтеграчійних процесів. Звернено увагу на процес інтеграиї̈ вищяої школи у європейський освітній простір як якісно новий етап міжнародних відносин у иіий галузі, основними ознаками якого є: інтенсифікаиія традиџійних міжнародних зв'язків; уніфікаџія освітніх систем різних країн; нові форми освіти, щчо виникли на основі використання інформачійних технологій; виникнення ринку освітніх послуг $і$ зростання конкурениії на ньому; інтеграчійні прочеси в освіті; світовий освітній простір. Наголошується на основних положеннях Педагогічної Конституиії Свропи, в якій пред-
\end{abstract}

ставлено перелік нових вимог до особистості педагога об'єднаної Свропи XXI cm., високий професіоналізм і компетенції якого спрямовуються на формування повноформатного суб'єкта європейського процесу. Представлено низку компетентностей і прикметних особливостей особистості майбутнього європейського педагога, а також типи навичок майбутнього paxівия «hard skills» $i$ «soft skills» та їхні складники. Розглянуто формулу «Чотири К» Програми освітнього альянсу "Партнерство з навчання у XXI столітті», щзо передбачає: креативність, кооперацію, критичне мислення та комунікативні навички. З'ясовано, що процеси євроінтеграції посилюють тенденції щзодо зростання професійних вимог до майбутнього викладача, де професіоналізм педагога є своєрідними щуаблями, 
етапами його руху до високих показників педагогічноі праці з притаманними йому відповідними рівнями й показниками.
Ключові слова: педагог, євроінтеграчія, освіта, професійні вимоги, компетентності, компетениії, «тверді навички», «м'які навички», професіоналізм.

\section{Ruslana SOICHUK,}

Doctor of Sciences (in Pedagogy), Professor,

Head at the Department of

Primary, Inclusive and Higher Education Pedagogy,

Rivne State University of the Humanities,

Rivne, Ukraine

ORCID: 0000-0001-5559-5388

e-mail: ruslanasoichuk@gmail.com

\section{MODERN REQUIREMENTS FOR THE FUTURE TEACHER IN THE UNITED EUROPE OF THE XXI CENTURY}

\begin{abstract}
The article updates and characterize the current requirements for the future teacher in a united Europe. The main tasks in teacher education and pedagogical activity in the context of European integration processes are revealed. It has been paid attention to the process of integration of higher education into the European educational space as a qualitatively new stage of international relations in this field. Accordingly, the main provisions of the Pedagogical Constitution of Europe are emphasized, which presents a list of new requirements for the personality of a teacher in a united Europe of the XXI century, whose high professionalism and competencies are aimed to form a full-fledged subject of the European process. A number of competencies and notable personality traits of the future European teacher are presented, as well as the types of skills of the future specialist «hard skills» and "soft skills» and their components.

The formula «Four K» of the Educational Alliance Program "Partnership for Learning in the XXI Century» is considered, which contains: creativity, cooperation, critical thinking and communication skills. It was found that the processes of European integration increase the tendency to increase professional requirements for the future teacher as a person of high educational level and spiritual and moral qualities, as the most important tool of educational influence on the younger generation, where professionalism is the steps of pedagogical work, so it has the appropriate levels and indicators. The professionalism of the future high education teacher is characterized as a manifestation of creative readiness of the individual to productively solve pedagogical tasks and form in the individual the level of competitiveness that will allow him to actively pursue professional activities, taking into account modern requirements for the teacher and current challenges.
\end{abstract}

Key words: teacher, European integration, education, professional requirements, competencies, capabilities, «hard skills», «soft skills», professionalism.

Постановка проблеми. Вибір Україною європейського шляху розвитку спонукає дослідників педагогічної компаративістики до пошуку та вивчення кращих традицій зарубіжного досвіду організації педагогічної освіти, професійної підготовки педагогічних кадрів у контексті завдань створення єдиного європейського освітнього простору. Означене відповідно передбачає: визнання стандартів освіти, встановлення еквівалентності академічних кваліфікацій, навчальних курсів, дипломів та ін. (Лазаренко, 2019, с. 53-54; Авшенюк, 2011; Ципко, 2012).

Усе зазначене вище підвищує вимоги до рівня професіоналізму майбутніх викладачів закладів вищої освіти (далі-3BO), передбачає розробку європейських критеріїв до оцінювання якості їхньої роботи, а отже, формує тенденцію розвитку західноєвропейської вищої педагогічної освіти щодо створення сучасної системи професійного відбору майбутніх педагогів як основи для формування конкурентоздатних фахівців із високим рівнем професіоналізму (Лазаренко, 2019; Цуняк, 2020).

Аналіз наукових досліджень і публікацій. Окремі аспекти проблеми досліджено в наукових працях учених: теорію та методологію професійної освіти (Н. Абашкіна, О. Дубасенюк, I. Задорожна, І. Зязюн, Н. Ничкало та ін.); різні аспекти підготовки педагогічних кадрів у провідних країнах світу (В. Андрущенко, Н. Бібік, О. Біда, С. Гончаренко, Н. Лавриченко, Л. Пуховська, А. Сбруєва та ін.).

Нормативно-правовим підгрунтям забезпечення означеної проблеми слугують Закони України «Про освіту», «Про вищу освіту», Державна національна програма «Освіта» (Україна XXI століття), Національна доктрина розвитку освіти України у XXI столітті, Концептуальні засади розвитку педагогічної освіти України та іiї інтеграції у європейський освітній простір, Концепція розвитку педагогічної освіти, Концепція громадянського виховання особистості в умовах розвитку української державності, Концепція «Нова українська школа» та ін., а також міжнародні документи у сфері вищої освіти: Рекомендації ЮНЕСКО про статус викладацьких кадрів вищих навчальних закладів (1997), Лісабонські домовленості (1997) щодо визнання кваліфікацій у галузі вищої освіти, декларації Болонського процесу стосовно створення європейського простору у сфері вищої освіти, Міжнародна стандартна класифікація освіти (МСКО-2011), Педагогічна Конституція Європи, розроблена професорами 
В. Андрущенком (Україна), М. Гунцінгером (Німеччина), А. Гайжутісом (Литва), що полягає у доповненні документом, який інтегрує уявлення про основи педагогічної підготовки у європейський освітній простір.

На думку I. Прокопенка, євроінтеграція - це добровільне зобов'язання України модернізувати вітчизняну систему вищої освіти з метою їі зближення з європейською освітою, без будь-якого тиску зверху, без жорсткої уніфікації (Прокопенко, 2013). У контексті проблеми дослідження «європейський простір» розглядають як простір єдиних ступенів, дипломів і єдиної системи контролю якості вищої освіти, що сприятиме мобільності роботи та мобільності студентів і викладачів завдяки створенню спільних організаційних принципів національних освітніх систем (системи ступенів, подібних принципів формування навчальних програм, вступних випробувань тощо) (Лазаренко, 2019; Прокопенко, 2013).

Поняття «інтеграція вищої школи у європейський освітній простір» потрактовують як якісно новий етап міжнародних відносин у цій галузі, основними ознаками якого є: інтенсифікація традиційних міжнародних зв'язків (мобільність людських та інтелектуальних ресурсів); уніфікація освітніх систем різних країн; нові форми освіти, що виникли на базі використання інформаційних технологій (онлайн-навчання, віртуальні університети); виникнення ринку освітніх послуг і зростання конкуренції на ньому; інтеграційні процеси в освіті; світовий освітній простір (Лазаренко, 2019; Прокопенко, 2013). Процеси євроінтеграції, посиленої інформатизації суспільства та мобілізації потенціалу системи самоорганізації навчання у вищій школі задля професійного становлення майбутніх викладачів закладів вищої освіти окреслюють нові підвищені вимоги до особистості педагога як до людини високого рівня освіти та духовних і моральних якостей, як найголовнішого інструмента виховного впливу на підростаюче покоління. Сучасне суспільство потребує самодостатньої, творчої та ініціативної молоді, здатної мобілізувати свій інтелектуально-духовний потенціал для досягнення як особистісного і професійного успіху, так і інтересів держави.

Мета статті - виокремити та схарактеризувати сучасні вимоги до особистості педагога об'єднаної Європи XXI століття.

Виклад основного матеріалу дослідження. Сучасний педагог в умовах сьогодення повинен досконало знати й оперувати засобами формування національної самосвідомості, організації діяльності, стимулювання, формування потреби вихованців у самовихованні, самовдосконаленні, уміло керувати власним психологічним станом, у власній педагогічній діяльності зорієнтовуватися передусім на професіоналізм.

Водночас студентська молодь, долаючи перешкоди, має бачити свою життєву перспективу, прямувати до власної самобутності, самодостатності, впродовж свого життєвого шляху мобілізувати приховані унікальні духовно-творчі можливості задля відстоювання обраних цінностей і досягнення позитивного результату у життєдіяльності. Зважаючи на це, підготовка нового педагога як професійного наставника нових поколінь для об’єднаної Європи є справою надважливою, а проєктування освітнього процесу в закладах вищої освіти на основі суб' єкт-суб'єктного рівноправного партнерства передбачає статус особистості як суб'єкта особистісного становлення в активній діяльності (Лазаренко, 2019).

Концептуальні засади розвитку вітчизняної педагогічної освіти у контексті європейських інтеграційних процесів окреслюють такі головні завдання освіти в умовах сьогодення:

- професійно-особистісний розвиток педагога на засадах особистісно орієнтованої філософії освіти;

- провадження двоциклової підготовки педагогічних працівників за освітньо-кваліфікаційними рівнями «бакалавр» та «магістр»;

- провадження фундаментальної, психолого-педагогічної, методичної, інформаційно-технологічної, практичної та соціально-гуманітарної підготовки науково-педагогічних працівників відповідно до вимог інформаційно-технологічного суспільства, що пов'язано із стрімким прогресом та розширенням спектра використання інформаційно-комунікаційних технологій у різних сферах освіти й суспільства загалом, що надає доступ до різноманітної інформації, способів комунікації та водночас потребує розвитку критичного ставлення у суб'єктів комунікації до інформаційного матеріалу;

- модернізація освітньої діяльності закладів вищої педагогічної освіти, що здійснюють підготовку педагогічних та науково-педагогічних працівників на основі традиційних і новітніх освітніх технологій, створення нового покоління дидактичних засобів;

- удосконалення системи професійного відбору молодого покоління на педагогічні спеціальності, розширення цільового прийому та запровадження підготовки педагогів на основі договорів;

- створення умов для безперервної освіти педагогічних і науково-педагогічних працівників у закладах вищої освіти та післядипломної педагогічної освіти (Цуняк, 2020, с. 87).

Варто зазначити про особливості зарубіжного досвіду підготовки педагогічних кадрів, який полягає в тому, що завдання сучасного педагога «більше не обмежуються навчальною аудиторією й процесом трансляції знань» (Бойчук, 2017), а передбачають педагогічну діяльність, як-от: володіння інноваційними педагогічними методами; здатність до рефлексії та формування в здобувачів освіти універсальних навчальних компетенцій; уміння організувати комфортне реальне освітнє середовище для здобувачів освіти; здатність провадити педагогічну діяльність у гетерогенних групах (різні культурні, соціальні й етнічні верстви), а також здатність до саморозвитку й професійного самоствердження; уміння моделювати професійну діяльність у процесі конструктивної співпраці 3 вихованцями, батьками, адміністрацією та громадою (Лазаренко, 2019; Прокопенко, 2013).

У контексті розширення комплексу взаємопов'язаних завдань педагогічної освіти (створення умов для розвитку та фахової підготовки здобувача вищої освіти - майбутнього педагога, який провадитиме освітню діяльність у сучасному інформаційно-освітньому 
середовищі, та формування у нього високих духовноморальних якостей як базису становлення української інтелігенції; сприяння професійному становленню, самовдосконаленню педагогів; стимулювання інноваційної діяльності як фактора розвитку творчого, відповідального й успішного професіонала, агента змін) проведення педагогічного аналізу бачення професійної підготовки педагогів, розгортання експериментальної роботи 3 комплексного застосування поліаспектних підходів є вагомим і перспективним у вимірі побудови цілісної моделі освітнього процесу професійної підготовки майбутніх педагогів у закладах вищої освіти (Сойчук, 2020, с. 5).

Посутнім видається звернення до Педагогічної Конституції Європи, в якій представлено перелік нових вимог до особистості педагога об'єднаної Європи XXI ст., високий професіоналізм і компетенції якого спрямовуються на формування повноформатного суб'єкта європейського процесу - людини глибоких знань i культури, носія гуманістичної філософії, світогляду і моралі, національних і загальнолюдських цінностей, виховання вмінь, потреби і прагнення щодо їхньої реалізації у європейському і світовому життєвому просторі (Стаття 6. 4) (Педагогічна Конституція Європи, 2013).

Доцільно зауважити, що основні положення Педагогічної Конституції Свропи базуються на вагомих аксіологічних складниках, що пов'язані з орієнтацією освітнього процесу в закладах вищої освіти на досягнення найвищого морально-духовного розвитку, та потенційних можливостей особистостях, детерміновані на засвоєння загальнолюдських і національних цінностей; полягають у забезпеченні психолого-педагогічних умов виявлення, розвитку та реалізації пізнавальної самостійності й смислотворчої самодіяльності особистості, її становленні як творця власного життя, здатного прогностично робити свідомий вибір і відповідати за дії, вчинки, а також адекватно, мобілізовано й компетентнісно реагувати на зміни, виклики життя та постійно самовдосконалюватися й досягати успіху (Педагогічна Конституція Свропи, 2013; Бех, 2008).

Отже, у Педагогічній Конституції Свропи ключову увагу звернено на:

1. Основні педагогічні иінності (толерантність, демократія, миролюбство, екологічна безпека, права людини і солідарність, милосердя і совість, відповідальність).

2. Головні завдання підготовки педагога (формування здатності до практичної навчально-виховної діяльності як динамічного поєднання етичних цінностей і когнітивних, метакогнітивних, міжособистісних і практичних умінь та навичок, знань та розуміння).

3. Основні компетентності особистості, що окреслені не лише поінформованістю, а й рівнем інтелекту, волі, здібностей, цінностей тощо.

Слід зазначити, що Міжнародна комісія Ради Свропи ввела в обіг поняття «компетентність» із таким тлумаченням: здатність особистості долати труднощі задля успіху, що передбачає набуття, обробку та засвоєння нових знань, умінь і навичок у поєднанні із ціннісними ставленнями, надбаннями пізнавального й життєвого досвіду, що сприяє мобілізації до практичної дії. Визначальними характеристиками компетентності осо- бистості є мотивація та впевненість (Савченко, 2011). У зв'язку з цим важливу увагу звернено на формування ключових компетенцій особистості, а саме: політичних і соціальних (здатність відповідати за себе та свої вчинки, брати участь у вирішенні актуальних питань, демократичних процесах тощо); міжкультурних (толерантне ставлення до представників інших національних спільнот, їхньої культури та цінностей, розуміння відмінностей і вміння взаємодіяти з іншими тощо); комунікативних (знання та використання різновиду вербальної і невербальної комунікації, іноземних мов тощо); інформаційно-комунікативних технологій-компетенцій (наявність критичного мислення, IКТ тощо); самоосвіту впродовж усього життя (особистого, професійного, соціального) (Савченко, 2011; Сойчук, 2016).

Компетентність як продукт освітньої діяльності це результат саморозвитку та самоорганізації особистості, узагальнення іiі діяльнісного та особистісного досвіду. Власне, за компетентнісного підходу навчальна діяльність набуває дослідницького характеру та сама стає предметом засвоєння. Зважаючи на це, студентська молодь самостійно визначає алгоритм вирішення завдання, усвідомлює його характер, оцінює отриманий досвід, здійснює самоконтроль ефективності дій, учинків, поведінки, тобто виробляє навички вирішення життєво важливих проблем (Сойчук, 2016).

У ракурсі грунтовного висвітлення компетентностей як умов і результату повноцінного освітнього процесу О. Савченко зазначила, що їх характеризують «як комбінацію знань, умінь та ставлень у відповідному контексті діяльності людини, а ключову компетентність як таку, що формують передусім для особистісного розвитку, активного громадянства, соціальної інтеграції....»; а також зробила висновок про особистісну та соціальну цінність компетенцій і їхню необхідність і корисність кожному вихованцю та суспільству загалом (Савченко, 2011 , с. 5). Знані українські вчені І. Бех, В. Кремень, О. Савченко, доробки яких є особливо цінним внеском у розроблення теоретичних і методологічних основ компетентнісного підходу, визначили такі категорії компетентностей: автономну діяльність (здатність захищати та піклуватися про права, потреби, бути відповідальним за інших; здатність складати особисті проєкти, здійснювати реалізацію планів; здатність діяти в широкому контексті); інтерактивне використання засобів (здатність інтерактивно використовувати мову, символіку, тексти; здатність використовувати знання, інформаційну грамотність; здатність застосовувати нові інтерактивні технології); уміння функціонувати в соціально різноманітних (гетерогенних) групах (здатність успішно взаємодіяти з іншими; здатність співпрацювати; здатність вирішувати конфлікти) (Савченко, 2011; Сойчук, 2016).

У Педагогічній Конституції Свропи подано низку компетентностей особистості майбутнього європейського педагога XXI ст., серед яких:

1) комунікативна компетентність (зокрема, сучасний педагог має вільно володіти кількома європейськими мовами);

2) компетентність самоідентичності;

3) компетентність справедливості;

4) лідерська компетентність; 
5) дослідницько-аналітична компетентність;

6) здатність навчатися впродовж життя;

7) емпатія - здатність розуміти переживання учня чи студента та співпереживати в процесі спілкування) (Педагогічна Конституція Європи, 2013).

4. Головні стратегії успішної діяльності педагога, серед яких: автентичність, своєрідність, візуалізація знань, демократичність, діалогічність, дослідництво, інтегративність, конструктивізм, лідерство, особистісна зорієнтованість, послідовність, рефлективність, здатність до розвитку, соціальна спрямованість, спирання на відповідний досвід, співробітництво, цілеспрямованість.

5. Ціннісний складник практичної підготовки майбутніх педагогів, що полягає у наскрізному характері й такому, що відбувається впродовж життя, де головною метою $є$ інтегрування майбутнього фахівця в систему суспільних відносин, формування громадянських якостей, активної громадянської позиції.

6. Академічну мобільність, котра сприяє формуванню кроскультурних цінностей, толерантності та налаштованості на співпрацю (Педагогічна Конституція Свропи, 2013; Лазаренко, 2019; Прокопенко, 2013).

Аналіз наукової літератури та нормативно-законодавчих документів засвідчує те, що в умовах сьогодення до майбутніх викладачів закладів вищої освіти висуваються нові професійні вимоги, що дають їм право стати конкурентоспроможними фахівцями та зреалізувати свій творчий потенціал у будь-якій державі світу. Зважаючи на це, європейському педагогу притаманні:

1. Свропейська ідентичність: він не відмовляється від національної ідентичності, а прагне до єдності в різноманітності. Для увиразнення окресленої проблеми видається посутнім згадати запропоноване академіком I. Бехом трактування ідентичності як «внутрішнього, суб'єктивного стану особистості, в якому виражається усвідомлення нею себе як своєрідної стійкості особистості, самототожності, переживання постійно наявного «Я», його збереження» (Бех, 2013, с. 22). Саме переживання $є$ важливою ознакою характеристики особистості щодо іiї ідентичності. Учений пов'язав ідентичність зі структурною цілісністю особистості та звернув увагу на доцільність ії співвідношення з ідентифікацією як механізмом і процесом, що сприяє формуванню ідентичності.

2. Європейські знання: європейський педагог знає про інші зарубіжні системи освіти, орієнтується в питаннях освітньої політики на рівні ЄС та поціновує вітчизняну систему освіти у зіставленні з європейськими зразками.

3. Свропейський мультикультуралізм: педагог плекає власну культуру та з повагою ставиться до інших культур.

4. Європейська мовна компетентність: розмовляє якнайменше двома європейськими мовами з різним рівнем компетентності.

5. Свропейський професіоналізм: має освіту, що дозволяє викладати у будь-яких європейських країнах, обмінюватися досвідом із колегами, проводити наукові дослідження.

6. Європейське громадянство: європейський педагог - громадянин Європи, поважає та плекає демократичні цінності.
7. Свропейські виміри якості: процес забезпечення якості педагогічної освіти враховує погляди, інтереси й запити різних стейкхолдерів та гарантує належне освітнє середовище.

8. Свропейська академічна та професійна мобільність передбачає налагодження співпраці із вітчизняними та закордонними закладами вищої освіти (Лазаренко, 2019).

У сучасному професійному середовищі особливу увагу звернено на два типи навичок, прикметних для майбутніх фахівців:

- «hard skills» («тверді навички») - це професійні, технічні навички, котрі наочно можна продемонструвати (знання мови, програмування тощо);

- «soft skills» («м'які / гнучкі навички») - це навички, вияв яких наочно складно перевірити, продемонструвати (комунікативні, організаторські, управлінські тощо) (Махначова, Мідляр, 2017; Сойчук, 2021).

У контексті проблеми дослідження посутнім видається інтерес до Програми освітнього альянсу «Партнерство з навчання у XXI столітті». Учені у межах означеної програми досліджували формулу «Чотири К», яка містить: креативність, кооперацію, критичне мислення та комунікативні навички. Екстраполюючи означену формулу в середовище закладу вищої освіти, можна визначити чотири складники «soft skills» майбутнього викладача ЗВО:

Креативність як здатність майбутніх викладачів генерувати інноваційні ідеї, що передбачає нестандартне й критичне мислення («вихід за межі традиційності», ризик тощо), прагнення до творчості. До методів формування креативності слід віднести: «мозковий штурм», метод кейсів, командну роботу, моделювання, ділові й рольові ігри тощо. Показниками креативності $€$ : кількість, оригінальність та інноваційність, продуктивність ідей (презентації, програми, моделювання тощо).

Критичне мислення як здатність майбутніх педагогів вирішувати проблему в умовах недостатньої / надмірної поінформованості, що передбачає: аргументацію фактів, оцінку та самооцінку результатів діяльності. До методів формування критичного мислення у майбутніх педагогів належать: підготовка звітів, повідомлень 3 оцінкою певного виду діяльності; «асоціативний кущ», «карта розуму», «дерево рішень», дискусії, диспути, полілоги тощо.

Комунікативність як здатність майбутніх викладачів до конструктивного обміну інформацією. Методи формування комунікативності у майбутніх викладачів: диспути, дискусії, «відкритий мікрофон», «відкрита трибуна», презентація результатів дослідження (відеопрезентації, виступи на семінарах, конференціях, форумах тощо).

Кооперативність як здатність майбутніх викладачів працювати в команді, що передбачає: комунікативну компетентність; уміння та навички вирішення конфліктів (толерантне ставлення до думок інших здобувачів освіти та колег; уміння приймати компромісне рішення); управлінську компетентність. Поціновується вміння бути відповідальним та надійним командним гравцем, дотримуватися своєї ролі у команді, не «підставляти» інших колег задля задоволення особистих 
інтересів. Методи формування кооперативної здатності майбутніх викладачів: колективні творчі справи, проєкти, групові види роботи тощо (Програма освітнього альянсу, 2018; Сажієнко, 2020; Сойчук, 2021).

Ураховуючи зазначене вище, слід зауважити, що формування «soft skills» майбутнього викладача 3ВО базується на основних положеннях, дотримання яких $€$ необхідністю задля подальшого професійного самоствердження, зокрема: самоосвіта; тестування щодо профорієнтації та саморозвитку; безперервне навчання і розвиток комплексного характеру (знайомство 3 новими професіоналами; вирішення щораз більш складних завдань; ефективна організація та планування самовдосконалення, саморозвитку; різноманітні формати навчання за чітко визначеними напрямами задля професійного самоствердження); щоденне інформування щодо новин у професійній сфері, знання сучасних зарубіжних та вітчизняних тенденцій (нові тренди, зміни, актуальні питання, події, заходи тощо), ефективне використання отриманої інформації, участь у заходах різного рівня; постійний розвиток особистісних та професійних навичок у процесі роботи над новими проєктами та завданнями; використання можливостей неформальної освіти (тренінги, семінари, форуми, майстер-класи, спеціальні навчальні курси та ін.) (Сажієнко, 2020; Сойчук, 2021).

Таким чином, в умовах євроінтеграції спостерігаються тенденції щодо зростання професійних вимог до майбутнього викладача закладу вищої освіти, де професіоналізм педагога $\epsilon$ тим етапом його руху до високих показників педагогічної праці, що знаходить своє відображення в таких рівнях:

- оволодіння професією відповідно до вимог євроінтеграції, адаптації до професійної діяльності;

- педагогічної майстерності як провадження на високому рівні кращих досягнень європейського педагогічного досвіду; здатність до реалізації особистісно орієнтованого навчання тощо;

- самоактуалізації педагога в професії, самоусвідомлення та професійного самоствердження, вироблення індивідуального стилю;

- педагогічної творчості як збагачення педагогом досвіду своєї професії за рахунок особистої творчої діяльності, створення нових педагогічних систем навчання й виховання (Грицяк, 2009; Лазаренко, 2019; Цуняк, 2020).

Професіоналізм майбутнього викладача ЗВО виявляється у творчій готовності особистості до продуктивного розв'язання педагогічних завдань і формування в особистості того рівня конкурентоспроможності, що дозволить їй активно зреалізувати професійну діяльність, ураховуючи сучасні вимоги до особистості педагога та виклики сьогодення. До таких показників професіоналізму належать: володіння професійними духовними цінностями та їхнє дотримання у життєдіяльності; сформованість професійної самосвідомості, мислення тощо; засвоєння на високому рівні професійних знань, способів і дій, технік і технологій, методик, форм, методів та прийомів (Лазаренко, 2019; Цуняк, 2020).

Висновки. Отже, процеси євроінтеграції та посиленої інформатизації суспільства підвищують професійні вимоги до майбутнього викладача ЗВО як до людини високого рівня освіти, духовних і моральних якостей, що детермінує мобілізацію потенціалу самої системи самоорганізації навчання в закладах вищої освіти України. У зв'язку з цим в умовах сьогодення надважливою справою $є$ підготовка педагога нової генерації як професійного наставника нових поколінь, що передбачає проєктування освітнього процесу в закладах вищої освіти на основі суб'єкт-суб' єктного рівноправного партнерства.

Таким чином, розкрити повною мірою поліаспектну проблему професійної підготовки майбутніх викладачів в одній науковій розвідці доволі складно, тому ми звернули увагу передусім на стислу характеристику сучасних вимог до особистості майбутнього педагога об'єднаної Європи.

Перспективи подальших наукових пошуків убачаємо в детальному аналізі компетентностей особистості майбутнього європейського педагога XXI ст., розробці та впровадженні ефективних форм і методів організації освітнього процесу в закладах вищої освіти.

\section{СПИСОК ВИКОРИСТАНОЇ ЛІТЕРАТУРИ}

Лазаренко, Н. І. (2019). Професійна підготовка вчителів у педагогічних університетах України в умовах євроінтеграції: монографія. Вінниця: ТОВ «Друк плюс». 365 с.

Авшенюк, Н. М. (2011). Пріоритетні стратегії СС щодо професійного розвитку вчителів на сучасному етапі. Професійне становлення особистості: проблеми і перспективи: матер. VI Міжнар. наук.-практ. конф. Хмельницький. С. 27-32.

Ципко, В. (2012). Інтеграція України до Європейського освітнього простору з позиції філософського виміру освіти. Вища школа. № 6. С. 44-50.

Цуняк, О. П. (2020). Система професійної підготовки майбутніх магістрів початкової освіти до інноваційної діяльності: дис. ... доктора пед. наук: 13.00.04. Інститут педагогічної освіти і освіти дорослих імені Івана Зязюна НАПН України. Київ. 517 с.

Прокопенко, І. Ф. (2013). Інноваційні технології підготовки вчителів в умовах євроінтеграції. Теорія $i$ практика управління сочіальними системами: філософія, психологія, педагогіка, соиіологія. № 2. С. 81-85.

Бойчук, В. М. (2017). Теоретичні і методичні основи художньо-графічної підготовки майбутнього вчителя технологій: дис. ... доктора пед. наук: 13.00.04. Вінниця. 494 с.

Сойчук, Р. Л. (2020). Погляд на проблему формування національної ідентичності майбутніх учителів: виховний аспект. Професійна підготовка майбутніх педагогів: теорія та практика: монографія / О. В. Боровець, С. Б. Бричок, Р. Л. Сойчук та ін.; за наук. ред. Р. Л. Сойчук. Рівне: видав. О. Зень. 236 с.

Педагогічна Конституція Європи. Преамбула. (2013). Вищца освіта України. № 3. С. 111-116. URL: https://svitovid6.webnode.com.ua/news/pedagogichnakonstitutsiya-jevropi/ (дата звернення: 20.05.2021).

Бех, І. Д. (2008). Виховання особистості: підручник. Київ: Либідь. 848 с.

Савченко, О. Я. (2011). Ключові компетентності інноваційний результат шкільної освіти. Рідна школа. № 8/9. C. 4-8. 
Сойчук, Р. Л. (2016). Виховання національного самоствердження в учнівської молоді: монографія. Рівне: видав. О. Зень. 416 с.

Бех, І. Д. (2013). Ідентифікація у вихованні особистості. Рідна школа. № 4/5. С. 2-25.

Махначова, Н. М., Мідляр, А. К. (2017). «Soft skills» керівника підприємства. Глобальні та національні проблеми економіки. Миколаїв: Миколаївський національний університет імені В. О. Сухомлинського. Вип. 17. С. 380-383.

Програма освітнього альянсу «Партнерство з навчання у XXI столітті». (2018). URL: https://osvitoria. media/experience/rozvyvayemo-navychky-4k-kreatyvnistkrytychne-myslennya-komunikatsiyu-ta-komandnupratsyu (дата звернення: 20.05.2021).

Сажіснко, О. П. (2020). Формування фахової компетентності бакалаврів сфери комп'ютерних технологій у процесі професійної підготовки: дис. ... доктора філософії за спеціальністю 015 «Професійна освіта». Уманський державний педагогічний університет імені Павла Тичини. Умань. 272 с.

Сойчук, Р. Л. (2021). До проблеми формування soft skills у майбутніх викладачів ЗВО. Професійний розвиток педагога: зб. матеріалів Всеукр. наук.-практ. конф. (м. Рівне, 31 березня 2021 р.). Рівне: РДГУ. С. 63-73.

Грицяк, А. І. та ін. (2009). Європейський Союз: інституційно-правові основи та функціонування: навч.-метод. посіб. Київ: НАДУ.

\section{REFERENCES}

Lazarenko, N. I. (2019). Profesiina pidhotovka vchyteliv u pedahohichnykh universytetakh Ukrainy v umovakh yevrointehratsii [Professional training of teachers in pedagogical universities of Ukraine in the conditions of European integration: monograph]: monohrafiia. Vinnytsia: TOV «Druk plius». 365 s. [in Ukrainian].

Avsheniuk, N. M. (2011). Priorytetni stratehii YeS shchodo profesiinoho rozvytku vchyteliv na suchasnomu etapi [EU priority strategies for the professional development of teachers at the present stage]. Profesiine stanovlennia osobystosti: problemy i perspektyvy: mater. VI Mizhnarod. nauk.-prakt. konf. Khmelnytskyi. S. 27-32. [in Ukrainian].

Tsypko, V. (2012). Intehratsiia Ukrainy do Yevropeiskoho osvitnoho prostoru z pozytsii filosofskoho vymiru osvity [Integration of Ukraine into the European educational space from the standpoint of the philosophical dimension of education]. Vyshcha shkola. № 6. S. 44-50. [in Ukrainian].

Tsuniak, O. P. (2020). Systema profesiinoi pidhotovky maibutnikh mahistriv pochatkovoi osvity do innovatsiinoi diialnosti [The system of professional training of future masters of primary education for innovation]: dys. ... doktora ped. nauk: 13.00.04. Instytut pedahohichnoi osvity i osvity doroslykh imeni Ivana Ziaziuna NAPN Ukrainy. Kyiv. 517 s. [in Ukrainian].

Prokopenko, I. F. (2013). Innovatsiini tekhnolohii pidhotovky vchyteliv v umovakh yevrointehratsii [Innovative technologies of teacher training in the conditions of European integration]. Teoriia i praktyka upr. sots. systemamy: filosofiia, psykholohiia, pedahohika, sotsiolohiia. № 2. S. 81-85. [in Ukrainian].

Boichuk, V. M. (2017). Teoretychni i metodychni osnovy khudozhno-hrafichnoi pidhotovky maibutnoho vchytelia tekhnolohii [Theoretical and methodical bases of art and graphic preparation of the future teacher of technologies]: dys. ... doktora ped. nauk: 13.00.04. Vinnytsia. 494 s. [in Ukrainian].

Soichuk, R. L. (2020). Pohliad na problemu formuvannia natsionalnoi identychnosti maibutnikh uchyteliv: vykhovnyi aspekt [Vision of the problem of forming the national identity of future teachers: educational aspect]. Profesiina pidhotovka maibutnikh pedahohiv: teoriia ta praktyka: monohrafiia / O. V. Borovets, S. B. Brychok, R. L. Soichuk ta in.; za nauk. red. R. L. Soichuk. Rivne: vydav. O. Zen. 236 s. [in Ukrainian].

Pedahohichna Konstytutsiia Yevropy. Preambula [Pedagogical Constitution of Europe]. (2013). Vyshcha osvita Ukrainy. № 3. S. 111-116. URL: https://svitovid6. webnode.com.ua/news/pedagogichna-konstitutsiya-jevropi/ (data zvernennia: 20.05.2021). [in Ukrainian].

Bekh, I. D. (2008). Vykhovannia osobystosti [Personality education. Textbook]: pidruchnyk. Kyiv: Lybid. 848 s. [in Ukrainian].

Savchenko, O. Ya. (2011). Kliuchovi kompetentnosti - innovatsiinyi rezultat shkilnoi osvity [Key competencies are an innovative result of school education]. Ridna shkola. № 8/9. S. 4-8. [in Ukrainian].

Soichuk, R. L. (2016). Vykhovannia natsionalnoho samostverdzhennia v uchnivskoi molodi [Education of national self-affirmation in student youth: monograph]: monohrafiia. Rivne: vydav. O. Zen. 416 s. [in Ukrainian].

Bekh, I. D. (2013). Identyfikatsiia u vykhovanni osobystosti [Identification in the education of personality]. Ridna shkola. № 4/5. S. 2-25. [in Ukrainian].

Makhnachova, N. M., Midliar, A. K. (2017). «Soft skills» kerivnyka pidpryiemstva [«Soft skills» of the head of the enterprise]. Hlobalni ta natsionalni problemy ekonomiky. Mykolaiv: Mykolaivskyi natsionalnyi universytet imeni V. O. Sukhomlynskoho. Vyp. 17. S. 380-383. [in Ukrainian].

Prohrama osvitnoho aliansu «Partnerstvo z navchannia $u$ XXI stolitti» [The program of the educational alliance «Partnership for Learning in the XXI Century»]. (2018). URL: https://osvitoria.media/experience/rozvyvayemo-navychky-4k-kreatyvnist-krytychne-myslennya-komunikatsiyu-ta-komandnu-pratsyu (data zvernennia: 20.05.2021). [in Ukrainian].

Sazhiienko, O. P. (2020). Formuvannia fakhovoi kompetentnosti bakalavriv sfery kompiuternykh tekhnolohii $\mathrm{u}$ protsesi profesiinoi pidhotovky [Formation of professional competence of computer technology bachelors in the process of professional training]: dys. ... doktora filosofii za spetsialnistiu 015 «Profesiina osvita». Uman: Umanskyi derzhavnyi pedahohichnyi universytet imeni Pavla Tychyny. 272 s. [in Ukrainian].

Soichuk, R. L. (2021). Do problemy formuvannia soft skills u maibutnikh vykladachiv ZVO [On the problem of soft skills formation in future freelance teachers]. Profesiinyi rozvytok pedahoha: zb. materialiv Vseukr. nauk.-prakt. konf. (Rivne, 31 bereznia 2021 r). Rivne: RDHU. S. 63-73. [in Ukrainian].

Hrytsiak, A. I. ta in. (2009). Yevropeiskyi Soiuz: instytutsiino-pravovi osnovy ta funktsionuvannia [European Union: institutional and legal basis and functioning]: navch.-metod. posib. Kyiv: NADU. [in Ukrainian].

Дата надходження до редакиії: 30.07.2021 p. 
УДК 378.046.4. (044)

DOI: 10.37026/2520-6427-2021-107-3-48-53
Микола СОЛОВЕЙ,

кандидат педагогічних наук, доиент, декан факультету підвищення кваліфікаиії Хмельницького обласного інституту післядипломної педагогічної освіти, м. Хмельницький, Україна ORCID: 0000-0001-5520-7111 e-mail:nikolosolovey@gmail.com

\section{ПІДВИЩЕННЯ КВАЛІФІКАЦЇ̈ ПЕДАГОГІЧНИХ ПРАЦІВНИКІВ ЗАКЛАДІВ ПОВНОЇ ЗАГАЛЬНОЇ СЕРЕДНЬОЇ ОСВІТИ В СУЧАСНИХ УМОВАХ: ОРГАНІЗАЦІЙНИЙ АСПЕКТ}

\begin{abstract}
Анотація. У статті на основі дослідження сучасних нормативно-правових документів, теорії $i$ практики підвищення кваліфікації педагогічних працівників визначено та описано особливості організаціі ицього процесу в умовах вільного вибору і становлення альтернативних суб'єктів післядипломної освіти. Нами виокремлено інноваційні елементи, що мають суттєве значення в управлінні підвищенням кваліфікаиії педагогічних працівників закладів повної загальноі середньої освіти, виділено завдання та покрокові діi вчителя і керівника в річному управлінському ииклі.

Суть проиесу проявлясться у рефлексії педагогом особистого рівня професійного розвитку, виборі суб 'єкта, освітньої програми, форми і виду підвищення кваліфікації. В адмініструванні виокремлюємо прочееури планування, проведення педагогічної ради,
\end{abstract}

складання й затвердження плану, розробки інструментарію (наказів, положень, договорів, тощо) і визнання результатів підвищення кваліфікаиї̈. Визнання розглядаємо як колективну дію, спрямовану на встановлення відповідності документів про підвищення кваліфікації нормативним вимогам прийняття відповідного протоколу у формі рішення педагогічної ради. У загальному контексті пропонуємо ідею про внутрішнє положення щзодо визнання результатів підвищення кваліфікації, головним у якій є принцип законності. У нашому дослідженні ми вперше виділяємо загальні аспекти визнання, конкретне їх виявлення за основними формами підвищення кваліфікації.

Ключові слова: підвищення кваліфікації, річний циикл, самоаналіз, планування, оплата послуг, визнання.

Mykola SOLOVEY,

Candidate of Pedagogical Sciences,

Associate Professor, Dean of the Faculty of

Khmelnytsky Regional Institute

of Postgraduate Pedagogical Education,

Khmelnytsky, Ukraine

ORCID: 0000-0001-5520-7111

e-mail: nikolosolovey@gmail.com

\section{THE ORGANIZATION OF ADVANCED TRAINING OF PEDAGOGICAL WORKERS OF ESTABLISHMENTS OF FULL GENERAL SECONDARY EDUCATION IN MODERN CONDITIONS}

\begin{abstract}
The article describes the results of a study of modern legal documents on professional development of teachers. According to Article 27 of the Law of Ukraine «On Education» (2017), advanced training becomes annu$a l$, and the total number of academic hours is fixed and for employees of general secondary education can not be less than 150 hours. for five years. The law paves the way for the accumulation of formal, non-formal and informal education for five years. At the same time, it fixes the right to advanced
\end{abstract}

training in educational institutions that have the appropriate license or conduct educational activities under an accredited programme. This rule was further developed in Art. 51 of the Law of Ukraine "On complete general secondary education (2020), which guarantees the right to advanced training, primarily in the municipal institution of in-service pedagogical education located on the territory of residence, as well as in other educational institutions and entities that declare the possibility of such educational activities. 